Vol 1 No 1 Desember 2019

ARTIKEL PENELITIAN

\title{
PERBEDAAN EFEKTIVITAS EKSTRAK BIJI PALA (MYRISTICA FRAGNANS HOUTT) DENGAN DIAZEPAM BERDASARKAN DURASI TIDUR MENCIT SWISS WEBSTER
}

\author{
Bella Ayu Aprilya ${ }^{1}$, Debby Mirani Lubis ${ }^{2}$ \\ ${ }^{1}$ Fakultas Kedokteran, Universitas Muhammadiyah Sumatera Utara \\ ${ }^{2}$ Bagian Fisiologi, Fakultas Kedokteran, Universitas Muhammadiyah Sumatera Utara \\ Email: bellaaypr@gmail.com ,debbymiranilubis@gmail.com
}

\begin{abstract}
According to National Sleep Foundation in America, more than one third (36\%) in young adults aged 18-29 years old reported hard to wake up in the morning. Nutmeg seeds contain atsiri oil about $10 \%$ and miristin that have sedative effect. The purpose of this study is to prove that nutmeg seeds shorten sleep induction time and prolong sleep time. This type of research is experimental research with a post test only control group design. The samples used were 27 male Swiss Webster mice, which were divided into three groups. The first control group was given diazepam; the second group was given nutmeg seed extract dose of $7.5 \mathrm{mg}$; and the third group was given aquabides. The data obtained from the sleep duration of mice in each group. To determine differences in each experimental group, data with normal distribution were analyzed by one way ANOVA test and data with abnormal distribution were analyzed by the KruskalWallis test using SPSS 22.0 for Windows. The results of the Kruskal-Wallis test showed that sleep induction time had a value of $p=0.001$. Based on the one way ANOVA test, the result shows the length of sleep time from the treatment group has a significant difference to the control group with a value of $p=0,000$ and also showing a significant result to the comparison group with a value of $p=$ 0,000. Nutmeg seed extract (Myristica fragrans Houtt.) with a dose of $7.5 \mathrm{mg}$ can significantly extend the sleep duration of mice.
\end{abstract}

Keywords: nutmeg seeds extract, sleep duration.

Jurnal Pandu Husada

Fakultas Kedokteran (FK)

Universitas Muhammadiyah Sumatera Utara (UMSU) 
Vol 1 No 1 Desember 2019

\section{PENDAHULUAN}

Tidur bagi manusia adalah hal yang sangat penting, karena tidur dapat mengendalikan irama kehidupan manusia sehari-hari. Setiap manusia menghabiskan seperempat sampai sepertiga dari kehidupannya untuk tidur. Menurut penelitian, hampir setiap manusia pernah mengalami masalah susah tidur. Beberapa masalah susah tidur dapat diatasi oleh individu yang bersangkutan dan yang lain memerlukan bantuan dokter, maka diagnosis diri (self diagnose) menjadi sangat penting. ${ }^{1}$

Fungsi tidur adalah restorative (memperbaiki) kembali organ - organ tubuh. Kegiatan memperbaiki kembali tersebut berbeda saat Rapid Eye Movement (REM) dan Nonrapid Eye Movement (NREM). Nonrapid Eye Movement akan mempengaruhi proses anabolik dan sintesis makromolekul ribonukleic acid (RNA). Rapid Eye Movement akan mempengaruhi pembentukan hubungan baru pada korteks dan sistem neuroendokrin yang menuju otak. Selain fungsi di atas tidur, dapat juga digunakan sebagai tanda terdapatnya kelainan pada tubuh yaitu terdapatnya gangguan tidur yang menjadi peringatan dini keadaan patologis yang terjadi di tubuh. ${ }^{1}$

Gangguan tidur merupakan keluhan yang sering ditemukan sekarang. Tidak hanya orang dewasa, orang muda bahkan lanjut usia juga dapat mengalami gangguan tidur. Tidak memandang status kaya, miskin, pendidikan rendah maupun tinggi. ${ }^{1}$

Berdasarkan hasil survei internasional, pada penduduk Indonesia, tahun 2004 dari 238,452 juta penduduk sebanyak 28,053 juta orang yang mengalami insomnia. Hal ini diperkuat dengan hasil survei terbaru bahwa prevalensi insomnia di Indonesia adalah $10 \%$ dari jumlah penduduk, dan akan terus meningkat seiring berjalannya waktu. Terlebih lagi National Sleep Foundation menyatakan bahwa di Indonesia prevalensi penderita insomnia mencapai $70 \%$ paling sedikit seminggu sekali dan 30 juta orang sulit tidur setiap malamnya ${ }^{2}$

Prevalensi gangguan tidur setiap tahun cenderung meningkat, hal ini juga sesuai dengan peningkatan usia dan berbagai penyebabnya. Kaplan dan Sadock melaporkan kurang lebih 40-50\% dari populasi usia lanjut menderita gangguan tidur. Gangguan tidur kronik (10-15\%) disebabkan oleh gangguan psikiatri, ketergantungan obat dan alkohol. ${ }^{3}$

Menurut data Internasional of Sleep Disorder, prevalensi penyebabpenyebab gangguan tidur adalah sebagai berikut: Penyakit asma (61$74 \%$ ), gangguan pusat pernafasan (40$50 \%)$, kram kaki malam hari (16\%), psychophysiological (15\%), sindroma kaki gelisah (5-15\%), ketergantungan 
alkohol (10\%), sindroma terlambat tidur (5-10\%), depresi (65\%). Demensia (5\%), gangguan perubahan jadwal kerja (2-5\%), gangguan obstruksi sesak saluran nafas (1-2\%), penyakit ulkus peptikus $(<1 \%)$, narcolepsy (mendadak tidur) $(0,03 \%$ $0,16 \%)^{2}$

Pada orang yang mengalami gangguan tidur berkepanjangan akan terjadi perubahan siklus tidur biologik seperti penurunan daya tahan tubuh sehingga menurunkan konsentrasi kerja, mudah tersinggung, depresi, kurang konsentrasi, mudah lelah yang pada akhirnya dapat mempengaruhi keselamatan diri. Beberapa penelitian gangguan tidur yang berkepanjangan mendapatkan bahwa orang yang mengalami gangguan tidur 2,5 kali lebih sering mengalami kecelakaan mobil dibandingkan yang tidurnya cukup. ${ }^{4}$

Setiap tahun jumlah penderita gangguan tidur semakin lama semakin meningkat sehingga sering timbul masalah kesehatan. Hal ini mengganggu sehingga cenderung membuat masyarakat mempergunakan obat hipnotik, tanpa mengetahui penyebab yang mendasari penyakitnya, sehingga sering menimbulkan efek samping akibat penggunaan obat yang tidak adekuat. ${ }^{5}$

Penggunaan obat-obat hipnotik yang ada sekarang merupakan masalah tersendiri yang perlu diperhatikan.
Keefektifitasan dan keamanan obat yang digunakan, ditinjau dari aspek medis, perlu diperhatikan. Sedangkan dari aspek nonmedis yang perlu diperhatikan adalah timbulnya penyalahgunaan obat yang yang kini kian marak di masyarakat. Melihat dari kejadian tersebut di atas, diperlukan adanya obat tradisional yang efektif, aman, murah, dan mudah didapat untuk mengurangi masalah yang tersebut di atas, terutama untuk mengurangi terapi dengan berbagai macam obat. ${ }^{4}$

Indonesia merupakan pengguna tumbuhan sebagai obat terbesar di dunia sama seperti negara lain di Asia seperti Cina dan India. Hal ini ada kaitannya dengan kekayaan sumber daya alam yang dimiliki. Kekayaan alam di Indonesia memiliki berbagai macam tumbuhan berkhasiat obat, sampai saat ini beberapa tumbuhan tersebut belum diketahui dengan jelas manfaat dan khasiatnya bagi kesehatan. ${ }^{6}$

Tanaman pala (Myristica fragrans houtt) adalah tanaman asli Indonesia yang berasal dari pulau Banda. Tanaman pala berkhasiat sebagai penenang (transquilizer), ekspektoran, diuretik, antitusif, antipiretik dan antiradang. ${ }^{7}$

\section{METODE}

Jenis penelitian yang dilakukan adalah penelitian eksperimental post 
Vol 1 No 1 Desember 2019

test only control group design. Dalam $=2 \mathrm{n} \geq 17$

penelitian ini digunakan metode

$=\mathrm{n} \geq 17 / 2$

penelitian perbandingan kelompok $=\mathrm{n}=8,5 \quad$ (dibulatkan statis (statis group gomparison) yaitu dengan melakukan pengukuran yang dilakukan setelah kelompok perlakuan menerima program atau intervensi. Rancangan ini terdiri atas 3 kelompok, yaitu 1 kelompok perlakuan dan 2 kelompok control. Kelompok perlakuan terdiri dari $\mathrm{P}_{1}$ adalah ekstrak biji pala (Myristica fragnans houtt). Kelompok kontrol terdiri dari $\mathrm{K}_{1}$ sebagai kelompok kontrol positif yang diberi diazepam untuk kontrol negatif $\mathrm{K}_{2}$ diberikan aquabidest sebagai kontrol negatif. Hasil pengukuran tersebut kemudian dibandingkan dengan hasil pengukuran pada kelompok control yang tidak menerima perlakuan yaitu kelompok kontrol positif dan kontrol negatif.

\section{Sampel Penelitian}

Pengambilan sampel dilakukan secara random sederhana. Sampel penelitian ditentukan dengan menggunakan rumus Federer.

Penelitian menggunakan 3 kelompok, maka jumlah sampel yang dipergunakan di peroleh dari perhitungan sebagai berikut :

$$
\begin{aligned}
& =(\mathrm{n}-1)(\mathrm{t}-1) \geq 15 \\
& =(\mathrm{n}-1)(3-1) \geq 15 \\
& =(\mathrm{n}-1)(2) \geq 15 \\
& =2 \mathrm{n}-2 \geq 15 \\
& =2 \mathrm{n} \geq 15+2
\end{aligned}
$$

menjadi 9)

Digunakan 3 kelompok, maka 9x3 = 27

$$
\begin{aligned}
& \text { Cadangan }=25 \% \times 27 \\
& \qquad \begin{aligned}
\text { Total }= & 27+(2 \times 3) \\
= & 33 \text { mencit Swiss Webster } \\
& \text { Berdasarkan perhitungan }
\end{aligned}
\end{aligned}
$$
tersebut diperoleh bahwa masingmasing kelompok sampel mempergunakan 9 ekor mencit Swiss Webster, jumlah sampel secara keseluruhan yang dipergunakan dalam penelitian ini adalah 27 ekor mencit Swiss Webster kemudian disiapkan mencit tambahan sebanyak 2 ekor perkelompok apabila dalam penelitian tikus putih jantan tiba-tiba mati, jadi penambahan tikus $25 \%$ dari total sampel penelitian. Dan total mencit Swiss Webster sebanyak 33 ekor. Ini artinya setiap perlakuan terdiri dari 9 ekor sebagai sampel dan 2 ekor sebagai tambahan. Sampel penelitian diperoleh dari populasi simpel random sampling dengan kriteria inklusi dan eksklusi.

\section{Kriteria Inklusi}

Mencit Jantan Swiss Webster (20-30 gram), Dewasa (umur >3 bulan), Kondisi fisik sehat, Tidak dijumpai kelainan anatomi, Belum pernah 
Vol 1 No 1 Desember 2019

digunakan sebagai subjek penelitian sebelumnya

\section{Kriteria Ekslusi}

Selama observasi 7 hari tampak sakit (gerakan tidak aktif), Selama observasi 7 hari berat badan tikus menurun, Mencit Swiss Webster mati.

\section{HASIL DAN PEMBAHASAN}

Penelitian ini menggunakan sampel sebanyak 27 ekor mencit Swiss Webster dan dibagi menjadi 3 kelompok, yang masing-masing terdiri dari 9 ekor mencit yaitu kelompok kontrol positif, negatif dan perlakuan. Kelompok perlakuan terdiri dari P1 adalah ekstrak biji pala (Myristica fragnans houtt). Kelompok kontrol terdiri dari K1 sebagai kelompok kontrol positif yang diberi diazepam, sedangkan untuk kontrol negatif K2 diberikan aquabidest sebagai kontrol negatif. Hasil pengukuran durasi tidur tersebut kemudian dibandingkan dengan hasil pengukuran pada kelompok kontrol yang tidak menerima perlakuan yaitu kelompok kontrol positif dan kontrol negatif.

Berdasarkan hasil pengukuran durasi tidur, didapati nilai rata-rata kelompok kontrol positif yaitu 220.43 menit, pada kelompok kontrol negatif yaitu 137,35 menit, dan pada kelompok perlakuan didapatkan 287.74 menit.

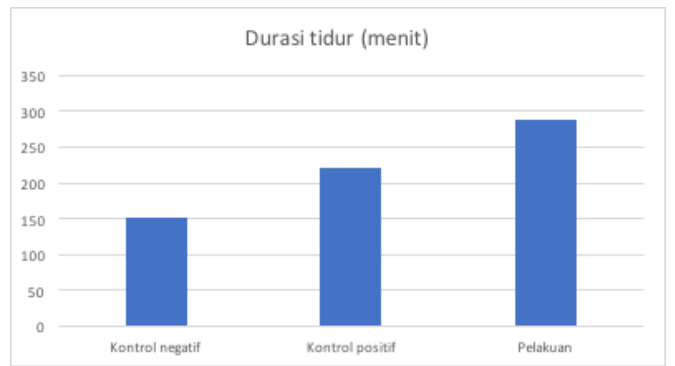

Gambar 1. Diagram Nilai Rata-Rata Durasi Tidur Antar Kelompok

\section{Deskripsi Durasi Tidur Kontrol Positif}

Pada pengukuran durasi tidur kelompok kontrol positif pada mencit yang diberikan diazepam, ditemukan gambaran sebagai berikut:

\begin{tabular}{|c|c|}
\hline No & Durasi tidur (menit) \\
\hline 1 & 210,36 \\
\hline 2 & 217,26 \\
\hline 3 & 232,04 \\
\hline 4 & 213,56 \\
\hline 5 & 226,28 \\
\hline 6 & 216,32 \\
\hline 7 & 217,24 \\
\hline 8 & 230,24 \\
\hline 9 & 220,56 \\
\hline
\end{tabular}

Didapatkan durasi tidur terpendek pada kelompok kontrol positif yaitu 210.36 detik dan yang terpanjang adalah 230.24 detik dengan nilai rata-rata 220.43 detik. 
Vol 1 No 1 Desember 2019

\section{Deskripsi Durasi Tidur Kelompok Perlakuan}

Pada pengukuran durasi tidur kelompok perlakuan pada mencit yang diberikan ekstrak biji pala, ditemukan gambaran sebagai berikut:

\begin{tabular}{|c|c|}
\hline No & $\begin{array}{c}\text { Durasi tidur } \\
\text { (menit) }\end{array}$ \\
\hline 1 & 280.32 \\
\hline 2 & 292.04 \\
\hline 3 & 282.46 \\
\hline 4 & 284.32 \\
\hline 5 & 287.56 \\
\hline 6 & 293.07 \\
\hline 7 & 290.48 \\
\hline 8 & 296.07 \\
\hline 9 & 283.36 \\
\hline
\end{tabular}

Didapatkan durasi tidur terpendek pada kelompok perlakuan adalah 280.32 detik, dan durasi tidur terpanjang adalah 296.07 detik dengan nilai rata-rata 287.74 detik.

\section{Deskripsi Durasi Tidur Kelompok}

Kontrol Negatif

\begin{tabular}{|c|c|}
\hline No & $\begin{array}{c}\text { Durasi tidur } \\
\text { (menit) }\end{array}$ \\
\hline 1 & 153,38 \\
\hline 2 & 152,28 \\
\hline 3 & 151,43 \\
\hline 4 & 153,48 \\
\hline 5 & 153,26 \\
\hline
\end{tabular}

\begin{tabular}{|l|l|}
\hline 6 & 152,42 \\
\hline 7 & 152,26 \\
\hline 8 & 153,43 \\
\hline 9 & 152,23 \\
\hline
\end{tabular}

Didapatkan durasi tidur terpendek pada kelompok kontrol negatif adalah 153,48 detik, dan durasi tidur terpanjang adalah 151,43 detik dengan nilai rata-rata 137,35 detik.

\section{Analisa Data}

\section{Uji Homogenitas Variansi}

Salah satu syarat untuk melakukan uji One-way Anova adalah sebaran data yang homogen. Hal ini dapat diuji menggunakan uji homogenitas variansi yaitu Levene statistic dengan syarat $\mathrm{p}>0.05$. Pada penelitian ini, ternyata data yang didapatkan tidak homogen yang dibuktikan dengan nilai signifikan $0.001 \quad(p<0.05)$ sehingga homogenitas variansi data tidak memenuhi syarat uji Anova.

\section{Uji Homogenitas}

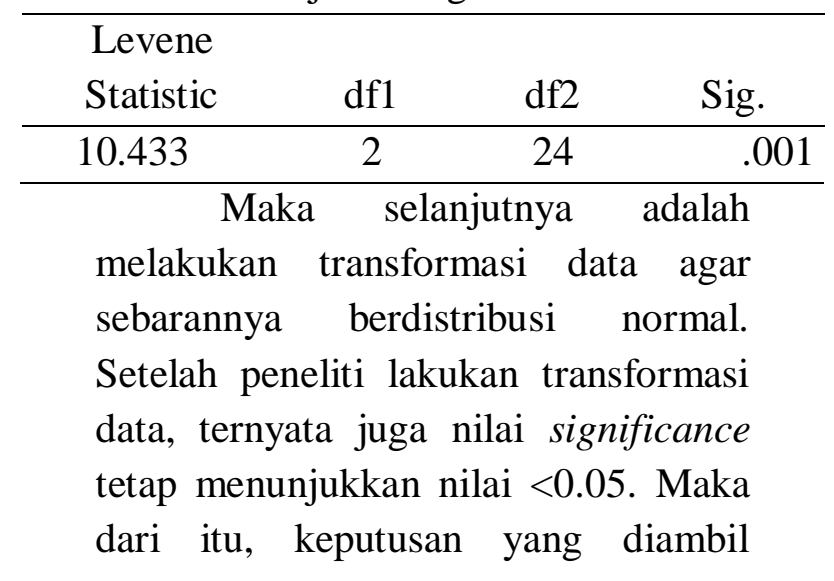

Jurnal Pandu Husada 
Vol 1 No 1 Desember 2019

adalah melakukan uji non-parametrik, yaitu menggunakan uji KruskalWallis.

\begin{tabular}{ccccc}
\hline Kelompok & Pembanding & Selisih & p & Kesimpu \\
& & & & \\
\hline Kontrol Positif & Kelompok Perlakuan & $-67.31333^{*}$ & 0.0001 & Signifik \\
& Kontrol Negatif & $220.42889^{*}$ & 0.0001 & Signifik \\
& Kontrol Positif & $67.31333^{*}$ & 0.0001 & Signifik \\
Kelompok Perlakuan & Kontrol Negatif & $287.74222^{*}$ & 0.0001 & Signifik \\
& Kontrol Positif & $-67.74333^{*}$ & 0.0001 & Signifik \\
Kontrol Negatif & Kelompok Perlakuan & $-135.0567^{*}$ & 0.0001 & Signifik
\end{tabular}

Pada tabel diatas, terlihat bahwa kelompok perlakuan memiliki selisih 67.32 menit lebih lama durasi tidurnya jika dibandingkan dengan kontrol positif. Terlebih dengan kontrol negatif, kelompok perlakuan memiliki perbedaan sebesar 135.057 detik, dan perbedaan sebesar 67.744 menit dengan kontrol positif. Hal ini juga didukung dengan nilai signifikansi yaitu 0.0001 dimana $\mathrm{p}<0.05$ yang dapat diartikan bahwa tiap kelompok memiliki perbedaan yang bermakna.

\section{PEMBahasan}

Berdasarkan hasil penelitian diatas, terlihat bahwa kelompok perlakuan memiliki durasi tidur paling panjang jika dibandingkan dengan kontrol positif ataupun kontrol negatif. Hal ini sejalan dengan penelitian yang dilakukan oleh Adnyana pada tahun 2012 yang menemukan bahwa jika dibandingkan dengan kelompok kontrol yang diberi diazepam, pemberian ekstrak biji pala memiliki durasi tidur yang lebih panjang. Penemuan ini menunjukkan bahwa pemberian ekstrak biji pala memiliki kemampuan lebih baik untuk mempertahankan durasi tidur jika dibandingkan dengan pemberian diazepam.

Hal ini juga selaras dengan penelitian yang dilakukan oleh Rahadian pada tahun 2009 yang melaporkan bahwa pemberian ekstrak biji pala dengan dosis $7.5 \mathrm{mg} / 25 \mathrm{~g}$ BB dapat memperpendek waktu induksi tidur dan dapat memperpanjang lama tidur mencit. Bedanya, pada penelitian Rahadian, efek tidur yang terkandung dalam biji pala memperlihatkan efeknya sampai waktu 180 menit. Artinya waktu pemulan sampai keadaan normal selama 180 menit belum tercapai.

Hal tersebut dapat dijelaskan bahwa saraf mencit terpengaruhi oleh zat-zat yang bersifat hipnotik yang terdapat pada biji pala. Penelitian dari Wallis menyatakan bahwa kandungan miristisin dan elimisin sebesar 2-18\% pada biji apla dapat bersifat merangsang tidur. ${ }^{4}$ Hasil signifikansi yang tampak pada penelitian ini juga sejalan dengan penelitian yang dilakukan oleh Hernaman pada tahun 2017 dimana peneliti tersebut menemukan hubungan yang signifikan 
Vol 1 No 1 Desember 2019

antara pemberian ekstrak biji pala terhadap sensasi anastesia pada hamster. Meskipun berbeda hewan coba, namun respon yang dihasilkan cenderung serupa.

Hernaman menemukan signifikansi yang amat nyata dimana diantara kelompok perlakuan yang diberi ekstrak biji pala memiliki perbedaan dengan kontrol positif dan kontrol negatif. Hal ini dikuatkan dengan penjelasan yang ditunjukkan oleh Winarti dan Nurdjanah pada tahun 2005 yang menyebutkan bahwa didalam pada minyak atsiri pala sekitar $5-15 \%$ terkandung senyawa meliputi pinen, sabinen, kamfen, miristicin, elemisin, isoelemisin, eugenol, isoeugenol, metoksieugenol, safrol, dimerik polipropanoat, lignan, dan neolignan. Beberapa senyawa memiliki efek bermacam-macam dapat dimanfaatkan sebagai obat sedatifhipnotik dan secara empiris, biji pala digunakan sebagai obat penenang. ${ }^{6}$

Hal serupa juga ditunjukkan oleh Sutanto pada tahun 2011, dimana peneliti menyatakan bahwa durasi tidur kelompok perlakuan berbeda sangat bermakna dibandingkan kelompok kontrol positif dengan $\mathrm{p}=0,0001 .{ }^{7}$ Penelitian di atas memberi gambaran bahwa biji pala dapat memberikan sensasi tenang dan dampaknya cukup lama sampai kembali pada keadaan semula.

\section{KESIMPULAN}

Ekstrak biji pala (Myristica Fragans houtt) dengan dosis 7,5 $\mathrm{mg} / \mathrm{kgBB}$ mencit memberikan pengaruh yang signifikan terhadap memperpanjang waktu durasi tidur mencit Swiss Webster.

\section{DAFTAR PUSTAKA}

1. Arifin AR, Burhan E. Fisiologi Tidur dan Pernapasan. Dep Pulmonologi Ilmu Kedokt Respirasi FKUI-SMF Paru RSUP Persahabatan, Jakarta. 2010:1-12.

2. Landau LD. 2011 Sleep in America Poll. Zhurnal Eksp i Teor Fiz. 2011:68.

3. Japardi I. Gangguan Tidur. Digit by USU Digit Libr. 2002:1-11.

4. Sholehah LR. Penanganan insomnia. E-Jurnal Univ Udayana. 2013:1-21.

5. Atmadja W. B. Fisiologi Tidur. $J$ Kedokt Maranatha. 2010;1(2):3639.

6. Nurdjannah N, MULYONO E. Teknologi Pengolahan Pala. Badan Penelitian dan Pengembangan Pertanian Balai Besar Penelitian dan Pengembangan Pascapanen Pertanian.2007.

7. Rodianawati I. Komposisi Kimia Oleoresin Biji Pala (Myristica fragrans Houtt) yang Diperoleh Dengan Ekstraksi Langsung dan Ekstraksi Bertahap. Sn-Kpk Ii. 2010:204-209 
Vol 1 No 1 Desember 2019

Jurnal Pandu Husada

Fakultas Kedokteran (FK)

Universitas Muhammadiyah Sumatera Utara (UMSU) 